\title{
Indigenous people and changing socio-cultural behavior: A case study of Toto tribes, Totopara.
}

\section{Los pueblos indígenas y el cambio de comportamiento sociocultural: un estudio de caso de las tribus toto, Totopara.}

\author{
Shahid Jamal, Aakash Upadhyay* and Rachna Dua** \\ Department of Geography, Delhi School of Economics University of Delhi- 110007 \\ *author for correspondence, email akashdse@gmail.com \\ ** Shyama Prasad Mukherji College, University of Delhi \\ ABSTRACT
}

As the saying goes "culture doesn't make people, it is the people who make culture". The are several tribes living in India and are trying to preserve their rich cultural heritage. Toto is an aboriginal Indo-Bhutanese tribe found in some parts of Alipurduar district in North Bengal. Unique to their culture is the idea of having only single wife and strongly advocate anti-dowry system unlike neighbouring tribal practices. As per the reports they are recognized as the smallest tribe on the Earth and are on the verge of complete extinction. Various cultural transformation and other developmental activities around the region is leading to declining Toto's population, which is further aggravated by Thalassemia virus, which is one of the silent killers of the tribe. It is alarming that an average lifespan of Toto's has suddenly declined to 35 years over the years. The basic objective of the study is to identify reasons beneath transformations of traditional livelihood and sudden decline of Toto tribe. Based on different research, global understandings and valuable readings, what instrumental steps can be taken to preserve and protect them. Primary survey and secondary data sources have been used for the data collection. A household survey was executed with the help of snowball sampling in December 2018 at Totopara in Madarihat block of Alipurduar district, West Bengal. Remedial and descriptive methods and qualitative techniques have been used for analysis of data. After the analysis, it was concluded that increasing the education and awareness level through workshops, documentaries, camps, public meetings, discussions, discourse, rallies, seminars and cultural programs would play an instrumental role to put a cap on the declining population of the locals and would lead to their sustainable growth and development.

Keywords Culture-Aboriginal- Extinction- Thalassemia-Sustainable Growth. 
Sustainability, Agri, Food and Environmental Research, (ISSN: 0719-3726), 9(3), 2021: 369-392 http://dx.doi.org/10.7770/safer-VONO-art2286

\section{RESUMEN}

Como dice el refrán "la cultura no hace a la gente, es la gente la que hace la cultura". Hay varias tribus que viven en la India y están tratando de preservar su rico patrimonio cultural. Toto es una tribu aborigen indobhutanesa que se encuentra en algunas partes del distrito de Alipurduar en el norte de Bengala. Única en su cultura es la idea de tener una sola esposa y abogar firmemente por el sistema anti-dote a diferencia de las prácticas tribales vecinas. Según los informes, son reconocidos como la tribu más pequeña de la Tierra y están al borde de la extinción completa. Varias transformaciones culturales y otras actividades de desarrollo en la región están conduciendo a la disminución de la población de Toto, que se ve agravada aún más por el virus de la talasemia, que es uno de los asesinos silenciosos de la tribu. Es alarmante que la vida media de Toto haya disminuido repentinamente a 35 años a lo largo de los años. El objetivo básico del estudio es identificar las razones detrás de las transformaciones de los medios de vida tradicionales y el repentino declive de la tribu Toto. Basado en diferentes investigaciones, entendimientos globales y lecturas valiosas, qué pasos instrumentales se pueden tomar para preservarlos y protegerlos. Para la recopilación de datos se han utilizado fuentes de datos primarias y secundarias. En diciembre de 2018, se realizó una encuesta de hogares con la ayuda de un muestreo de bola de nieve en Totopara, en el bloque Madarihaat del distrito de Alipurduar, Bengala Occidental. Se han utilizado métodos correctivos y descriptivos y técnicas cualitativas para el análisis de datos. Después del análisis, se concluyó que aumentar el nivel de educación y conciencia a través de talleres, documentales, campamentos, reuniones públicas, discusiones, discursos, mítines, seminarios y programas culturales jugaría un papel fundamental para poner un límite a la población en declive de los locales. y conduciría a su crecimiento y desarrollo sostenibles.

Palabras clave Cultura-Aborigen- Extinción- Talasemia-Crecimiento sostenible

\section{INTRODUCTION}

Tribe is a cluster of bands resides in an adjacent geographical area with the feeling of oneness through common language, rituals, culture, practices and dialects (Wolf, 2001). Tribal people are primitive inhabitant of our country (Devalle, 1990). They know the forest way of lifestyle only as forest provides them an abundance of food and protection (Xaxa, 1999). The forest nourishes them and Totos are one of them (Wenner-Gren Foundation, 1976). Totos are reputed as Mongoloid people, with flat nose, small eyes, broad and wide cheeks (Sinha and Pal, 1983). They generally have darker complex which shows they are nearer to the equator (Debnath, Das and Saha, 2019). According to anthropologists, the 
Sustainability, Agri, Food and Environmental Research, (ISSN: 0719-3726), 9(3), 2021: 369-392 http://dx.doi.org/10.7770/safer-V0N0-art2286

Toto's language and culture are very unique and totally distinguished from the neighbouring tribes like Koch and Bhutanese Sharchop (Singh, 2014). Totos live in an elevated bamboo huts, identifying themselves as Hindu and practice kindred marriage, whereby they stay in the same neighborhood even after the marriage (Basak et al. 2009). They worship nature like river, canal, animal, forest, Kholanala (Khola-river, Nala-small canal) and their pghosallace of worship is called as Gohati (Gupta, 2013). Initially, they are engaged in animal husbandry like cattle rearing of pig, cow, goat and agriculture like maize, finger millet, areca seeds, cardamom, ginger, orange, sal, chegun etc. (North Bengal Development Department, 2019). Nepali, Bengali and Bihari mainly influence Totos as they are surrounded by them which lead to transformation in their language (Hoque, and Ansar, 2015). Totos are considered as Mongoloid people, there is also a cultural difference with Doya community in terms of their food habits, clothes, deities and so on (Ghosal, 2016). They shifted to the Totopara after a conflict with the Doya community, which is a tribe of Bhutan and around 1980s, there was a spread of epidemic, which results in a sharp decline in their population (Singh, 2017). According to Anthropological Survey of India, Toto's population are described as endangered but their language is far more endangered than their population (Das, 2011). Totopara's native language is Nepali, Bengali, Urdu and English but majority of the people speaks Nepali. Nepali, Bihari, Bengali, Christian and Muslim dominates the area but majority of them belong to Nepali community (Chakrabarty and Sahu, 2013). However, Totos doing well in several fields and are duly becoming the part of the main stream of the region but in the field of education they are still backward (Dutta, 2014). Nowadays, Totos are exclusively found in some parts of Alipurduar district in North Bengal (Daw, 2015). Migrants from Bihar and Nepal dominates these areas and have good control over most of the economic activity of the area (Chaudhary, 2009).

\section{ORIGIN THROUGH THE PAGES OF TIME}

In the British India, an experienced civil servant under the seal of the then Government of India for the maiden time recognized Toto residing in the border of Bhutan and India (Sanyal, 1955). A small community Toto lived in a village viz. Totopara (Das, 1999). The village is located around $25 \mathrm{~km}$ away from Madarihat railway station in Alipurduar district of West Bengal state near Bhutan Border (Dutta, 2017). Toto tribe is considered as the smallest tribal community of the state with total population of 1574 and one of the 75 tribal communities of the country (Sarkar, 2015). The Ministry of Tribal Affairs, Government of India has listed Toto tribe under the PVTGs (Particularly Vulnerable Tribal Groups). The Ministry covers schedule tribes from 18 states/Union Territories of Andaman and Nicobar Islands 
Sustainability, Agri, Food and Environmental Research, (ISSN: 0719-3726), 9(3), 2021: 369-392 http://dx.doi.org/10.7770/safer-V0N0-art2286

(Press Information Bureau, 2018). The isolation of their location by stormy rivers like Torsha and Hauri, forest like Titi, mountains from Bhutan help then to protect and preserve their liberty and indignity (Majumdar, 2013). In the scenario of globalisation and privatisation it become very tough for any vulnerable to preserve their indigenous culture and Totos are not an exception to it (Chakrabarti et al. 2002). With the idea of Vasudhaiva Kutumbakam, they can preserve their rich cultural heritage as the idea is based on the theme that the whole world is a family where one is relative and other is stranger (Ghosh and Saha, 2017).

\section{CONTEXTUAL ISSUES}

Tribes are very important element of any societal system, but they have been dealing with various challenges over the year. There is an absence of any kind of transport connectivity to Totopara and to reach there, people have to cross several dry rivers which are filled up with water during the monsoon season (Mukherjee, 2017). They cure diseases like diarrhea, diabetes, dengue etc. by their traditional Ayurvedic method (Sanyal, 1973). They are facing very severe problems in the field of medical facilities mainly when the patients are in critical conditions (Majumdar, 1998). Poverty is not just a lack of money; it is not having the capability to realize one's full potential as a human being and Totos are one of the best examples of it (Dhargupta et al. 2009). Education is the most powerful weapon which can be used to change the world but there is no chapter of education in their lives and very rarely you will find any Toto with Master degree (De and Dutta, 2014). Previous state governments (Jyoti Basu and Buddhadeb Bhattacharjee) gave proper attention for their uplift like given scholarship, government job etc. but the current government has stopped all these schemes (Sengupta, 2015). Toto belongs to primitive Indo-Bhutanese tribal community, which resides in a small territory known as Totopara. They believed in both joint family and nucleated family but majority favour living in a joint family as it provides a sense of social security and protection from outsiders.

Study Area: Totopara is a small area in the foothill of the Himalayas, which is located at a distance of around 1.5-2 km from the Bhutan Border (Census of India, 2011). There lives a primitive tribe known as Toto, which is mainly originated from Bhutan. It lies between $26^{\circ}$ $50^{\prime \prime} \mathrm{N}$ to $26^{\circ} 83^{\prime \prime} \mathrm{N}$ latitude and $89^{\circ} 20^{\prime \prime} \mathrm{E}$ to $89^{\circ} 31^{\prime \prime} \mathrm{E}$ longitude (Fig. 1), which is spread over 8.08 sq. km (District Census Handbook, 2011). 
Sustainability, Agri, Food and Environmental Research, (ISSN: 0719-3726), 9(3), 2021: 369-392 http://dx.doi.org/10.7770/safer-VONO-art2286

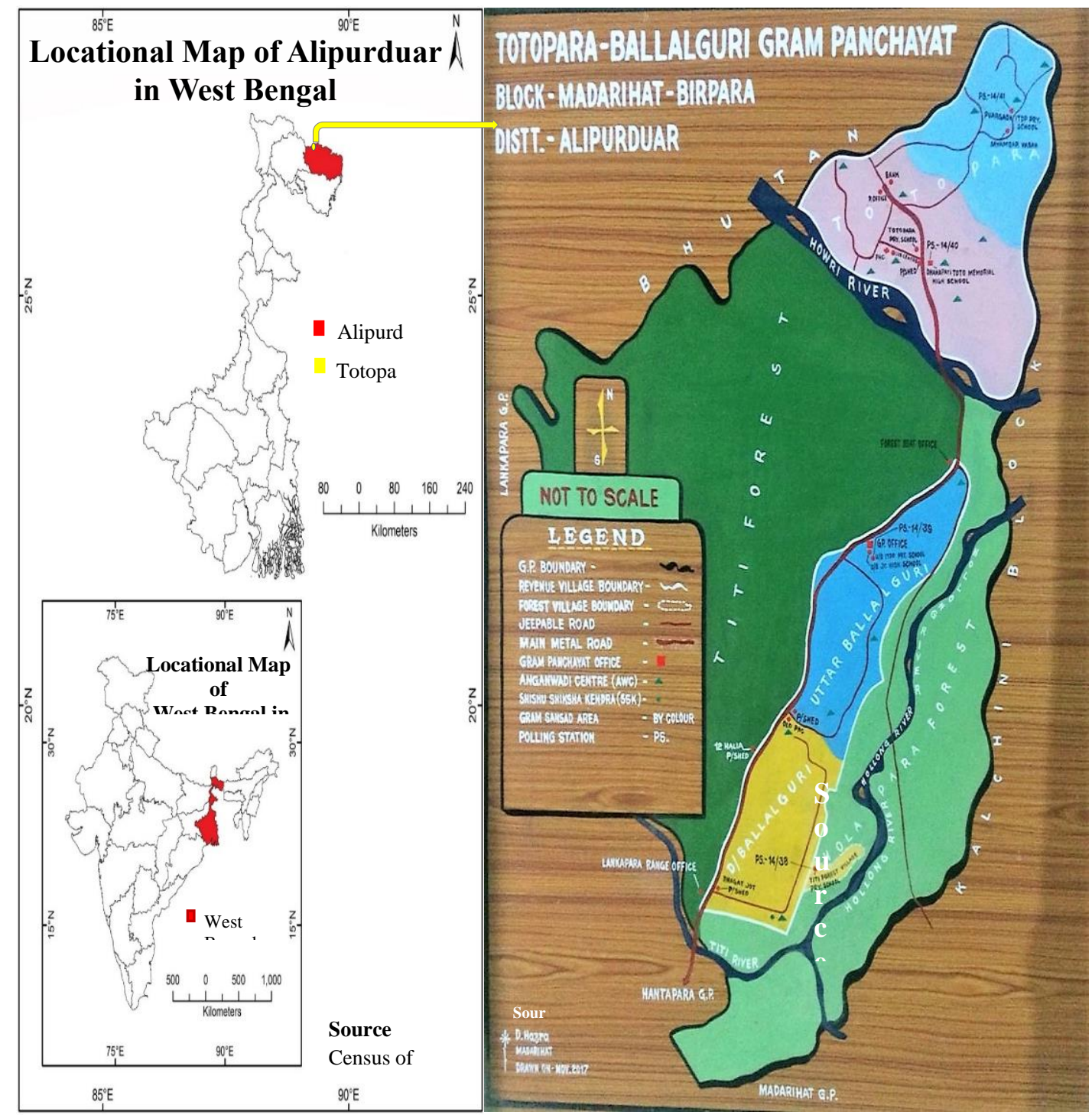

Fig. 1 Location Map of Study Area

The region has the mixed combination of Nepali, Christian and Muslim population where all are living in a harmony and peace (Biswas, 2009). Their philosophy is based on, when there is righteousness in the heart then there is beauty in the character (Dawn, 2014). When there is beauty in the character then there is harmony in the home. When there is harmony in the home then there is order in the nation. When there is order in the nation there is peace and peace and peace in the world (Kalam, 2015). The social fabric of the region is very strong as there is no violence against any community ever happened. Identification of Toto tribe is not an easy task, to understand who belongs to which community (Mukherjee et al. 1987). All of them are engaged in celebrating the teez and festivals of each other together 
Sustainability, Agri, Food and Environmental Research, (ISSN: 0719-3726), 9(3), 2021: 369-392 http://dx.doi.org/10.7770/safer-V0N0-art2286

as there is no hard and fast rule to celebrate the same (Saha, 1990). The total average number of literates in the region is $30.35 \%$, which is very low as compared to the national average of $74.04 \%$ (Biswas, 2013). The male literacy is $36.36 \%$ while the female literacy is 23. $53 \%$ in the region, which is also very low as compared to the national male and female literacy rate of $82.14 \%$ and $65.46 \%$ respectively (Census of India, 2011).

Research objective, analyze the remodeling traditional livelihood patterns of Toto tribe amid declining Population.

\section{DATABASE AND RESEARCH METHODOLOGY}

The present research is based on both primary and secondary database. Before conducting the field survey, review of various literature was done including journals, magazines, newspapers, books, research articles and government reports to achieve the desired result. It helped us to shape the research framework and draw probable conclusion. Data pertaining the tribe was also taken from Gram Panchayat Office (smallest administrative unit), as they conduct time to time census operation in the area. Other sources of secondary data include District Census Handbook, Census of India-2011, North Bengal Development Department, Ministry of Tribal Affairs, Wenner-Gren Foundation report. Different important information from the internet have also been incorporated to get the critical understanding of the study.

Primary survey was conducted in the study region with the help of interview method, semi-structured questionnaire, personal interview, informal and formal with the tribal folks. Some of the methods the researchers used for primary data collection were participatory observation, field visits, ontological, deontological techniques and analytical, historical and descriptive methods. During the primary survey an attempt was also made to go for ethnographic study, whereby the researchers tried to have a holistic idea about the ever changing tribal and future generation. Purposive participatory random sampling survey was conducted at different pockets of Totopara in December 2018 (Fig. 2). In addition to these methods group discussions and focused group discussion (FGD) were also conducted during the field visit obtain the desired outcome. After group discussions it was observed that, they were male dominant society, like patriarchal society system across India.

Then the data collected from primary and secondary sources were analyzed and interpreted. The data analysis was done using qualitative approach, some statistical tools like table and graphs and narratives. Based on the outcome, discussions were done and suggestion have 
been given. Some of the questions asked during the interview survey have been attached below (Appendix-1).

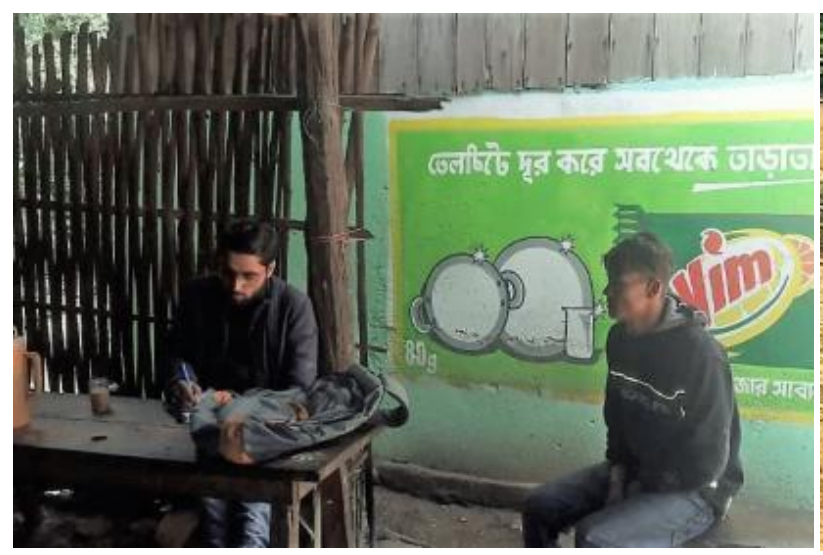

Fig. 2 Interview with Toto Tribe (Researcher, 2018)

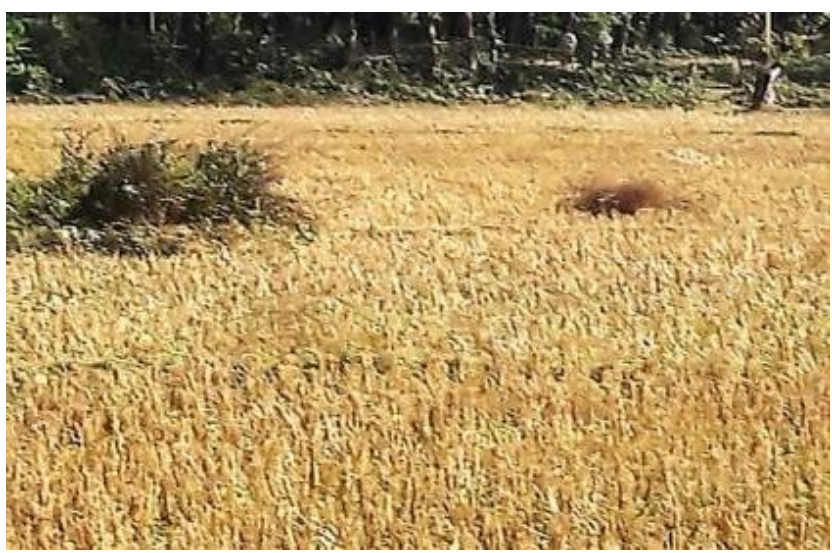

Fig. 3 Millet Field (Researcher, 2018)

\section{RESULT AND DISCUSSION}

Totos are the tribe of sub-Himalayas, they live a simple life with very basic use of locally available resources and belong to very poor community. They are renowned as one of the isolated tribes of the sub-Himalayan regions that is located between Bhutan and West Bengal (India). The tribe is undergoing with multiple sudden changes mainly because of globalisation, introduction of new technologies and other factors. Toto's struggle has interwoven with low economic, social and political status. However, Totos are covered under Schedule Tribes and are given legal protection under the Article 342 and 366 of the Indian Constitution. But they are not covered under the Particularly vulnerable Tribal Groups (PVTGs). Hence, are not capable to avail the special benefits. As a tribe, they face several struggles being accepted into the mainstream of the society. Some of the factors responsible for economic and cultural transformation of Totos are discussed below.

Constant Clashes: Totopara is located around two km from Bhutan border, which has cultural differences with the Bhutanese. One of the participants replied that these differences was one of major reason for constant clash between both the communities. As a result, the sex ratio of Toto tribe disturbed as in the clash mostly male used to take part and are killed by the Bhutanese. In this regard, there is sudden decline in the number of male populations in the tribe. The male population play a vital role in the reproduction process. The process of reproduction in the tribe reached to its lowest level in the era of constant clash and dispute with the Bhutanese. 
Sustainability, Agri, Food and Environmental Research, (ISSN: 0719-3726), 9(3), 2021: 369-392 http://dx.doi.org/10.7770/safer-V0N0-art2286

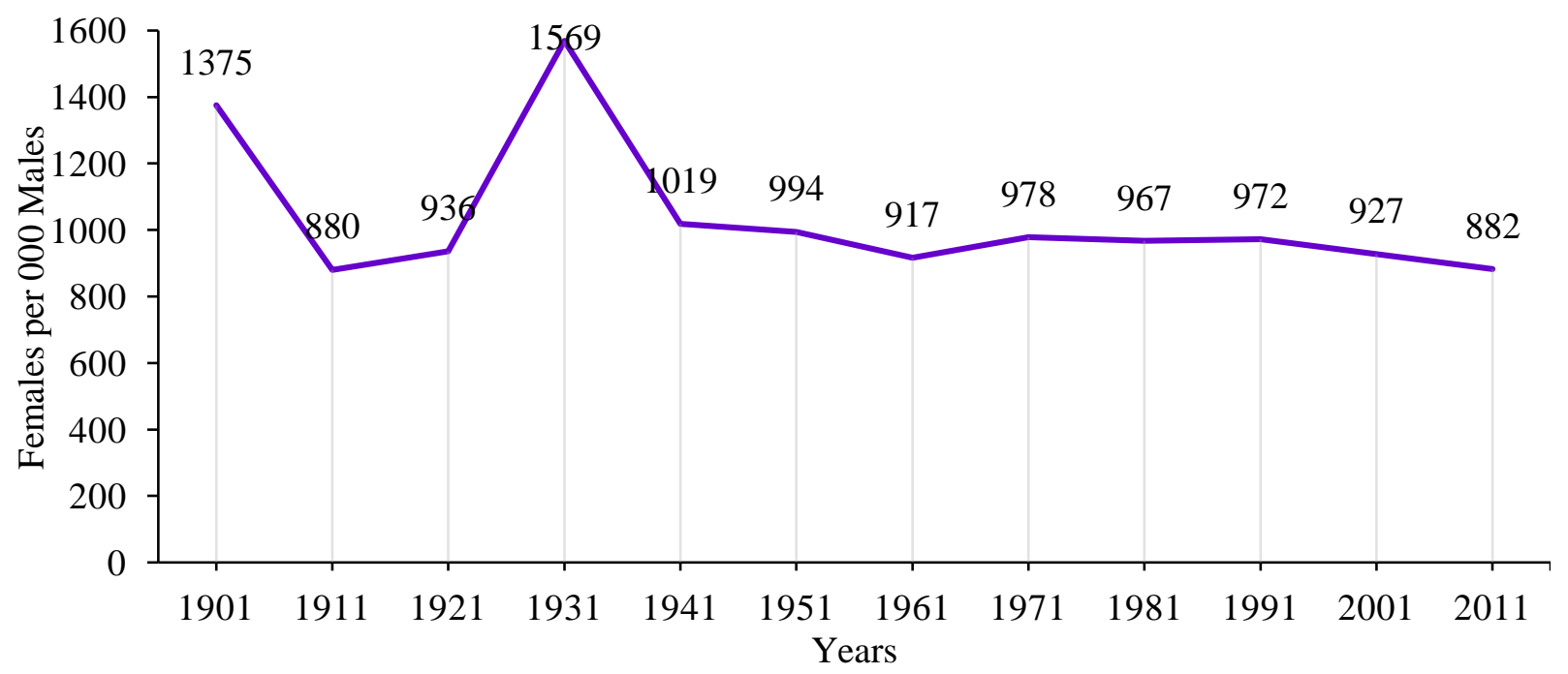

Fig. 4 Gender Ratio among Toto Tribe (Source Indian Statistical Institute, 2011)

But the government data shows inverse relation that the number of females per thousand males is declining (Fig. 4). In 1901, the number of Totos female per thousand males was 1375 and reached to its apex of 1569 in 1931 . Afterward, there is more or less declining trend in their female population and in 2011; it had reached to its lowest level of 882 since the last 110 years. According to the available data, if the trend continues, then the population of female in relation male will reach to below 600 in the coming 2-3 decades.

Outbreaks of Diseases: Between 1982-1985, there was a spread of deadly epidemic, which resulted in the wipe out of the Totos population from Totopara-Ballalguri. One of the respondents replied that during this period, Toto tribe infected by several dangerous diseases like tuberculosis, diabetes, thalassemia, pneumonia, measles, rubella and hepatitis. They don't even have self-care facility. It refers to the capability of an individual, family and society to prevent disease, promote health and manage disability and disease with or without the help of health-care workers. When anyone infected with any disease then they do the native incantation, sometimes it works and in case of severe diseases it couldn't work and the infected person died within a week. The poor infrastructure facilities of the area were also responsible for large number of the tribe death. Such a large scale of Totos' death could be minimize or stopped by early detection of the diseases and timely provision of the correct medicines and other medical facilities.

Poor infrastructure: Even today, the entire Totopara-Ballaguri area doesn't have any kind of road connectivity. One of the respondents replied that to reach the area you have to cross several rivers like I have crossed around 13 rivers. During the rainy season, the conditions of the road become worst as all the roads inundated under the water. While 
Sustainability, Agri, Food and Environmental Research, (ISSN: 0719-3726), 9(3), 2021: 369-392 http://dx.doi.org/10.7770/safer-V0N0-art2286

crossing the river, we have to very cautious that any small boulder can come under your foot and cause severe injury. No schools are there in the tribal area, if have schools then no teachers and non- availability of basic amenities like toilet, water supply, teaching board and the idea to get educated is lacking among them. Totos are residing in huts and none of them have pakka house. There is no supply of electricity to the area at all and that's why they perform all their activities during the day time like carry animal from one place to another. They collect their cooking fuel from the forest and, they travel 4-5 kilometers for better quality. There is no provision of Pradhan Mantri Ujjwala Yojana as they are much more comfortable with their traditional forest fuel instead of LPG cylinders under the scheme.

Livelihood sources: Their main source of livelihood is cattle rearing and particularly pigs rearing. Pigs rearing is done just under the first floor of their home. The functional morphologies of their home is divided into different floors like on the first floor their family members reside. There are no second floor as their house is made up of mud, thatches and khaprail. One of the participants replied that on the ground floor, they keep their livestock like pigs as it becomes very convenient for them to monitor their livestock from there. They feed pigs a good quality diet consists of millet, and soybeans which gives high energy to their cattle. After 2-3 years, they slaughter adult pigs and sell their meat in the market. Pig's fat is also sold at a good price. The fat after melting at high temperature oil comes out from it and that oil is used to make parathas and other eatable items apart from pain relief oil. Wild millet is another source of their livelihood. The grow the millets and sell it into the local markets.

Household Morphology and Food Habits: Totos build their house with clay, straw, bamboo and thatch. These are huts with four cornered walls. Kitchen, poultry rearing and pig rearing space remain separated from the central living in the hut. Their main foods are millet (Fig. 3). Now, they become enure with Bengali and Nepali foods like fish, meat, vegetables and rice. On every special occasion, they used to take their unique drink known as Eu. They prepared liquor Eu from fermented rice, marua, malt and powder and after completion is served in purva (mud glass) and poipa (wooden glass).

Cultural Diversity and Traditional Richness: Totos are divided into 26 different clans in total but each of them has surname of Toto. In the clan, they are also subdivided into several minor categories. One of the participants replied that they worship nature like forest, fire, mother earth, river and wind against idol worship and mazar worship. In that, Khula Nala (small rivers) is their main God. They do rooster sacrifice or bali and gives their blood to the almighty to impress them. The sacrifice ceremony done in a very delighted manner. There is a tradition that in which river and which colour of rooster sacrifice to be performed and with proper prescribe day and time. They celebrate around three festivals in a year namely. During 
Sustainability, Agri, Food and Environmental Research, (ISSN: 0719-3726), 9(3), 2021: 369-392 http://dx.doi.org/10.7770/safer-V0N0-art2286

September i.e. Bhado month, they celebrate Pongchu where they worship monsoon and khula nala as during that period monsoon is prevalent. Between November to October, they celebrate Nayu like the Durga puja and Kali puja. During March, they celebrate Sarde i.e., winter festival. Their place of worship is called as Gohati means sacred place or holy place for worship. Goshu is their traditional weapon used for animal sacrifice and in local Nepali language the weapon known as patan means patla. Patan is made up of iron, is around three feet long, which can easily through from some distance to kill the target.

Traditional Drink: The drink that they used to take is $100 \%$ natural with little added chemical substances, which is locally called as Eu. One of the participants replied that they drink their traditional and authentic rice bear (Eu) with the unique added ingredients like millets and in that finger millet. They have developed their own method of preparing the Eu. Indigenous knowledge used to ferment the rice at various levels to give distinct taste to it. When they dough the floor, then mixed it with some red chili powder, the power didn't make the bear spicy rather removes the spicy flavour of the bear and gives more better taste. They follow a unique system to grind the rice into a very fine powder then, they spread the powder on the floor of room. The floor of that room is covered with the fine bamboo object. Now, the spread power left for few days to dried up and on that white powder they keep coal to cover and protect from anyone don't put eyes on it. All these sacred activities are performed in a closed room where sunlight doesn't enter even during the daytime. They cover the rice with coal to show respect to their token of respect to the local deities. After 2-3 days, they mixed water in dried powder, then filtrate the ingredients by chapani. Now, some transformations in their traditional method of bear preparation can be seen. In this regard the practice of drying up the rice and floor can also be seen in the open field instead of earlier within the four walls of a closed room.

Diversification in Occupation: Agriculture is the most important and their hereditary work as they are doing from the generation. They have their own land and work as agricultural labourers on the field. One of the participants replied that traditionally, they are growing rice, finger millet, ginger, potato and orange. Now, with the increase in population and commercialization causes transformation from their traditional source of livelihood to another sources. It includes fishing, meat (pig) selling, general store, cellular shop, and some highly literate Totos are busy in the teaching profession. The prosperity of the agriculture is diminishing not only in Totopara but also across the country. With this regard, several protests and suicide cases are being registered over the years in agriculture sector. With this regard, the divide between the Toto and non- Toto communities in the region is increasing over the years. 
Sustainability, Agri, Food and Environmental Research, (ISSN: 0719-3726), 9(3), 2021: 369-392 http://dx.doi.org/10.7770/safer-VONO-art2286

Customary Norms: Totos marry within their tribe to protect and preserve their identity and ethnicity. There are 4 kind of marriages happened in the tribe. It includes marriage by escape (Chor-behoea), love marriage (Lamalami), capture marriage (Sambehoea) and negotiation marriage (Thulbehoea). Marriage between the cousins also happens which lead to birth of child with thalassemia disease. In thalassemia, there is a constant bleeding from mouth and nose and has no permanent treatment yet. Thalassemia is one of the main reasons for the constant decline of the population. Recently, Anthropological Survey of India remarked that an average living standard of Totos are 35 years only which is a great cause of concern for their existence. They believed in Hindu religion, and worship goddess Cheima and God Ishpa. They perform several customs and rituals like offering animal sacrifice to please the almighty.

Women's Living Condition: Among Totos monogamy is common, but polygamy is also not prohibited among themselves. The love marriage is allowed but divorced is not at all acceptable as it is considered as the evil and undermine their rich cultural society. One can remarry after the death of her or his spouse. A woman can't marry her dead husband's brother but a man can marry his dead wife's sister. This kind of narrative shows that the condition of women in the tribe is as pathetic as other part of the country.

Unemployment: Totopara generates better employment opportunities but among the young Totos, the unemployment rate is very high and is increasing year after year. One of the participants replied we the native of this region are suffering the most in terms of employment while the migrants of the region are well-off like Nepali and Bihari. Few and very few Totos are there who did their graduation and post-graduation respectively in different subject from the reputed institute (Fig. 5). Rita Toto was one of them and she is the first women who did her graduation in 2010. Even then, they are not able to get the desired employment.

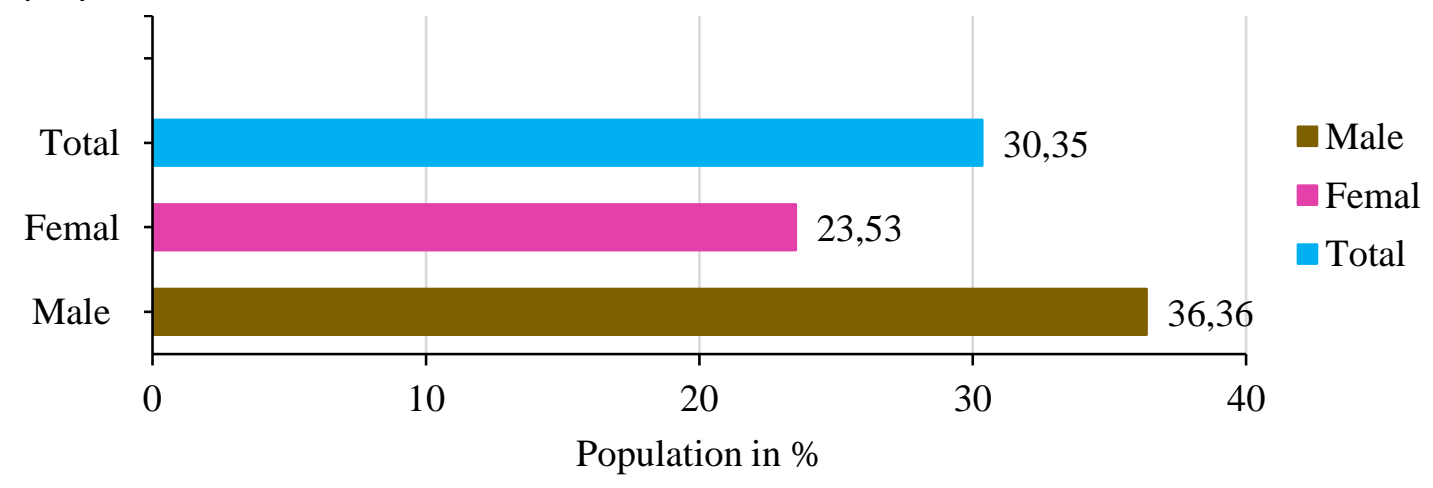

Fig. 5 Literacy Rate in Totopara (Source Gram Panchayat, 2011) 
The reason behind is that they are not as sharp as other Schedule Tribes (STs) in the districts and state. Other STs have evolved from their backwardness over the years while Totos are still as backward as they were before. However, they did make improvement in their standards but the needed transformation is far back from other STs of the district. When a graduate Totos didn't find any opportunity in teaching sector then unwillingly they start their hereditary work i.e., agriculture. In agriculture sector, disguised unemployment is very high means with the increase in the number of labourers the marginal productivity of the farm is continue to be the same.

Safeguarding Tribes - Reservation: The union government reserves $7.5 \%$ quota for STs but problem is that only prosperous STs communities like Aguri in the state and Meena from Rajasthan in the national level takes away most of the reservation benefits. While the communities like Toto are still far backward in the field of education. According to Census 2011 , only $30.35 \%$ of Totos are literate, the figure itself reveals that how backward are they. One of the participants replied that they demand the government about the special quota exclusively for Toto in the STs category in the region. Toto tribe is found in the geographical area of Totopara only. The tribe is nowhere scattered in any part of the district, state or country and their population growth rate is declining with steady pace though their population is increasing (Fig. 6 and 7). In this context, the government have to provide some sorts of reservation in the government jobs to improve their living standard.

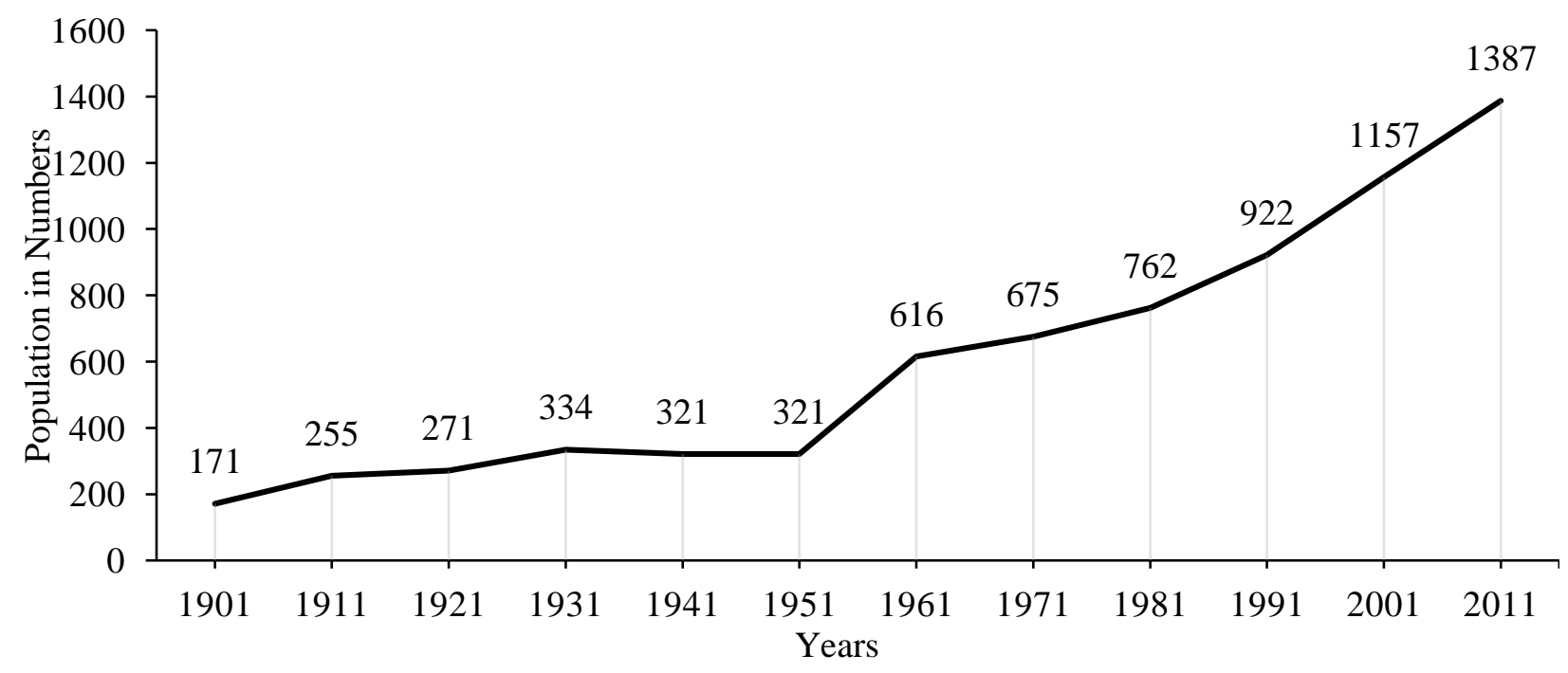

Fig. 6 Toto's Demographic Profile, 1901-2011 (Source Indian Statistical Institute, 2011 


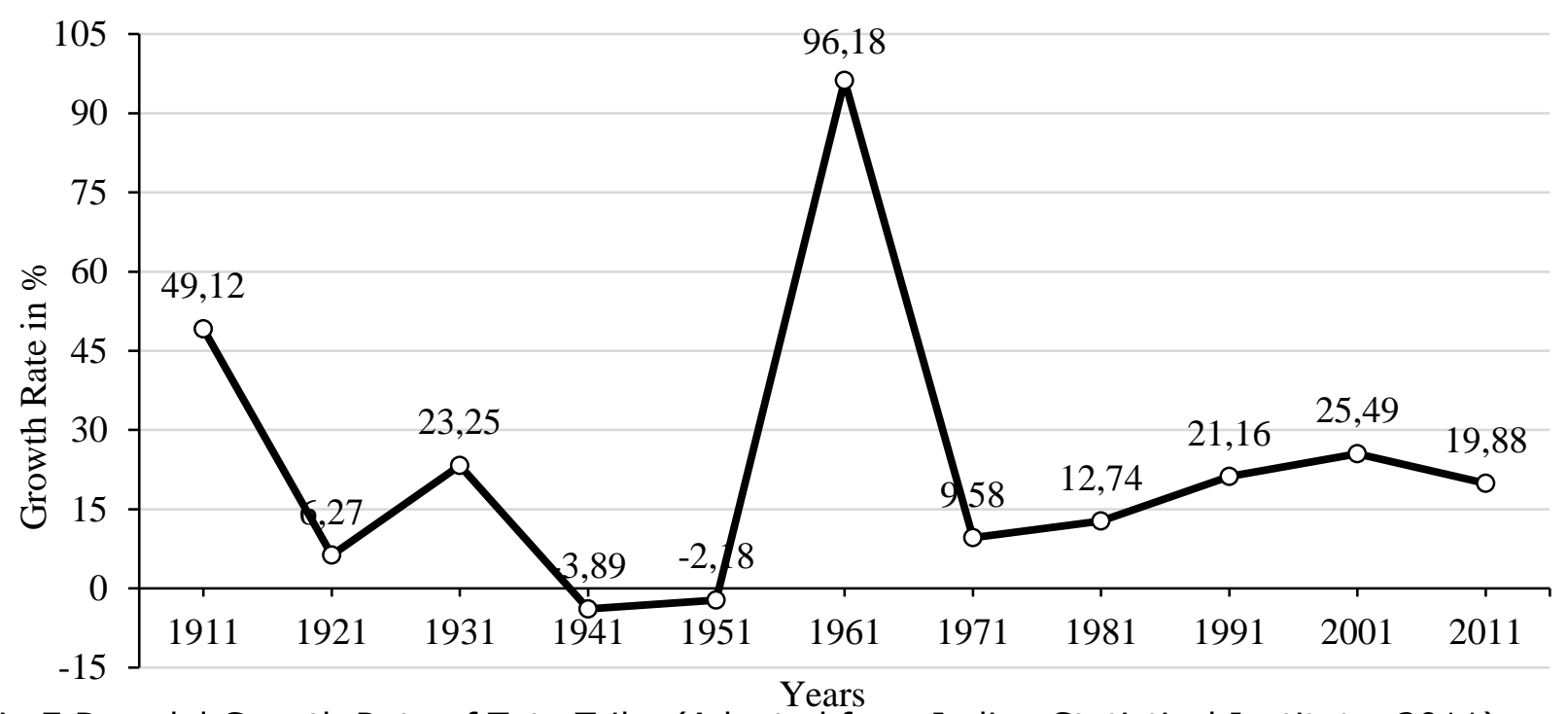

Fig.7 Decadal Growth Rate of Toto Tribe (Adopted from Indian Statistical Institute, 2011)

Social Practice of Marriage: Toto tribe do marriage within their community following their traditional customs and rituals. Totos believed that their marriage is fixed in the heaven and here they are performing the formal rituals. One of the participants replied that earlier, they do marriage within their community only and it was mandatory as per their constitution but now there are some relaxation to choose the life partner. In this regard, there are some Totos who married with non-Totos like Nepali. Inter tribe marriage is also one of the reasons for the decline of their number. In the manner, if a female Toto married with a male Nepali then she automatically becomes Nepali just after the marriage. Such type of marriage is not at all in favour of Toto tribe but if a male Toto married with the female Nepali then that girl automatically becomes Toto just after the marriage and it is good.

Identity Crisis: During the primary survey, it was observed that an outsider can't makes difference between a Toto and a Nepali as both looks very similar to each other and course they are not same. Their physical appearance like nose, ear, eye and hair looks very similar. In this way, the Nepalese are misrepresented as Toto by the government officials which is a great threat to their identity (Fig. 8 and 9). Such kinds of misperception from the mind of the officials have to be sorted out with the highly experienced officials. The officials can also take help of the locals to identify Toto and non-Toto population in the region. One of the participants replied several non-Totos are there who are getting benefits in the name of Toto like taking monthly ration under the food security. Such kinds of activities are misrepresenting the number of Totos in the region apart from threat to their identity. It is 
Sustainability, Agri, Food and Environmental Research, (ISSN: 0719-3726), 9(3), 2021: 369-392 http://dx.doi.org/10.7770/safer-V0N0-art2286

one of the reasons that there are discrepancies between the government's population data and Totos' actual population in Totopara.

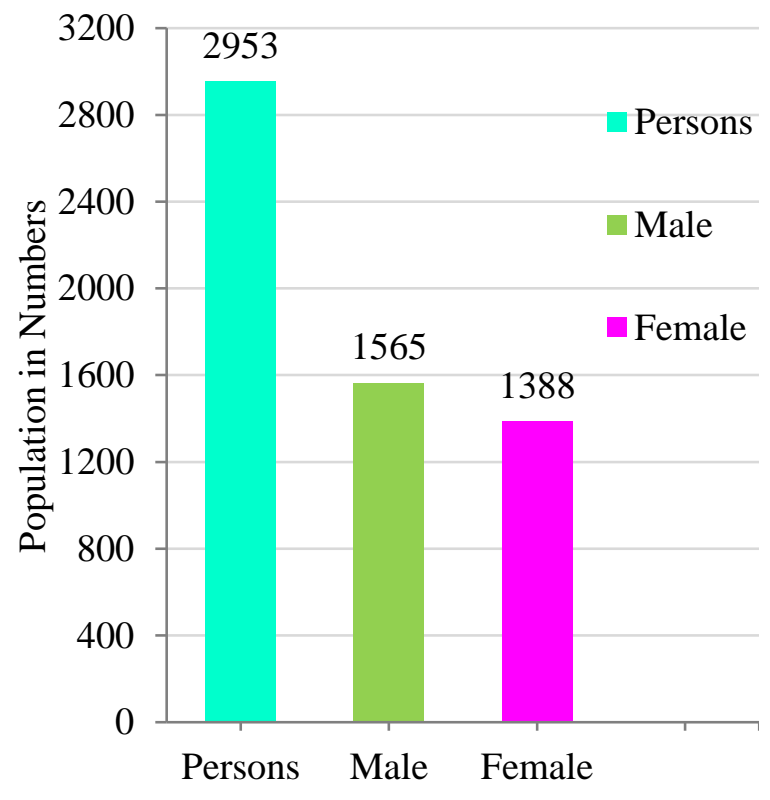

Fig. 8 Total Population in Totopara (Adopted from Gram Panchayat, 2011)

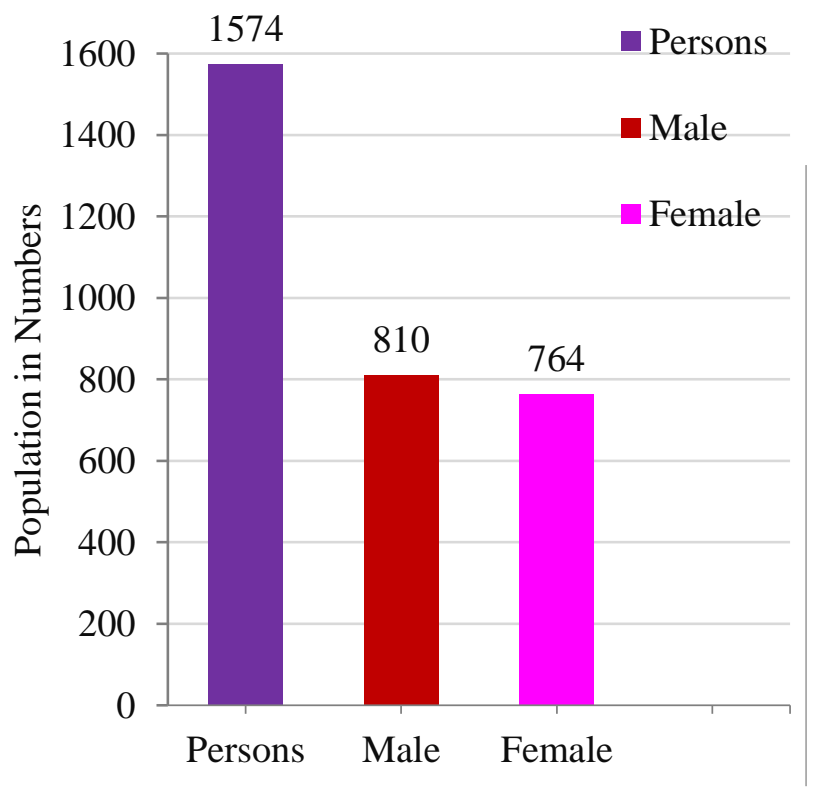

Fig. 9 Toto's Population (Adopted from Gram Panchayat Office, 2011)

Economic Prospects - Tourist Destination: Totopara's location is very strategic as it lies between India and Bhutan border. The scenic beauty of the region attracts good number of tourists. One of the participants replied that of the important tourist destinations are as follows Chalsa, Gorumara, Jaldapara and Chapramari, Torsha River and Hauri River and Titi forest. 
The region is also famous for timber cultivation. All these activities result in a lot of capital generation. The unique quality of the region is that you don't need any kind of permit or tourist visa to visit Bhutan. Tadink region of a Bukka block from Sanksi district, Bhutan lies on the border area that touches India. The Border is open and anyone can visit either side of the border it is because of friendly relationship and soft power diplomacy signed between both the countries. Tourism provides some source of livelihood to Totos. They serve as tourist guide as they are sons of soil bad being living there from the generation.

\section{Wave of Modernization - Communication Services}

Totopara has $3^{\text {rd }}$ Generation (3G) mobile internet connectivity provided by Airtel and BSNL (Fig. 10). It is a big achievement for the region. One of the participants replied that they have the connectivity but the speed is very slow and disrupted frequently. The region doesn't have a good number of 3G customers that's why the cellular companies are no showing their interest to provide their services. The required infrastructure facilities for the mobile connection is very poor. To solve the internet problem interested mobile companies are continuously working to install their new mobile towers and boost the efficiency of existing towers installed in the region. The mobile connectivity is very important as it connects them what is happening outside Totopara. It helps them to get latest information about what new schemes and programmes government launches for them.
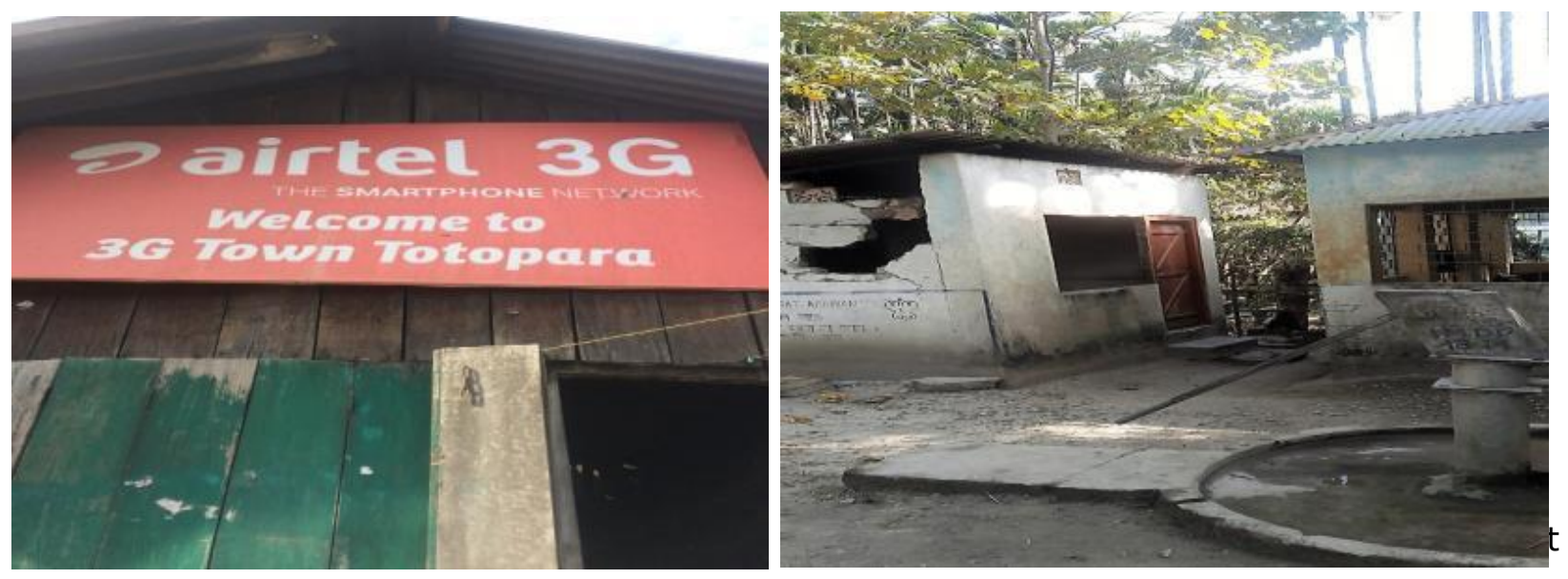

(Primary Survey, 2018)

Man-Animal Conflict: Totopara faces man-animal conflict as the region contains good number of plants, trees and vegetation. The area is situated inside the forest which results in the often roaming of wild animals towards human settlements. Totopara is situated on the northern border of the Jaldapara National Park. The park is one of the well-known for wildlife in Dooars and for the large population of one-horned rhinoceros and elephants. With the increase in human population, conversion of forest lands for non-forest purposes like 
Sustainability, Agri, Food and Environmental Research, (ISSN: 0719-3726), 9(3), 2021: 369-392 http://dx.doi.org/10.7770/safer-V0N0-art2286

agriculture results decrease in the forest areas. Then, the wild animals of the park migrate towards the human settlements in search of food. Big animals like elephants and one horned rhinoceros did the maximum damage to their house (Fig. 11). Most of the animals attract towards their kitchen room as the smell of cooked food reach to them then, they moved in the direction from where the smell is coming. Sometimes, the animals attack on the locals when they didn't find the food or when come in their way. One of the participants replied that it is easier to shoo or protect themselves from small animals like wolf and nilgai but become very problematic from big animals. Wild animals like nilgai destroy their crops and for that they made wiring, net on their field. Through this, they protect their field but there are many cases that some animals who tried to enter in the field have died as their neck was badly injured and suffocation and sometimes bleeding.

The other side Socio-Economic status: One of the participants replied that their life is just like a pig. Whose duty is to eats fodder, chew them to the maximum and excrete. Totos are getting the ration only and nothing else from the government ration shop, they eat the food and excrete as a pig do. The participant narrative shows that they had lost their right to life with liberty and personal dignity. They also humiliated on the ration shop and they have accepted them as the part of their life as no important person are their representative to take stand from their side. They are living a life without any hope as there is no hope except the darkness in their life. This is their life cycle without any kind of kind of attention is paying by the current state government. They don't have any kind of representation, contribution and quota in sports and academics in the government. Some political benefits like vote bank politics may be the reason beneath this and it may be anything. Even they don't know the exact reason. They have one thing clear in their mind that till TMC government rule in the state will not take any significant step so that they live there with liberty and personal dignity. 19. Water Crisis and Conservation

Totopara lies in the up-line area with the increase in population the area also faces water crisis. The problem becomes acute during winters as entire rivers of the region gets dried up while during summers water availability is sufficient. The region receives enough amount of rainfall that's it didn't face water problem during summers. Two boring system have been established in the area. The concerned water department stores water in the reservoirs through borings. The area has two reservoirs but only one is in working condition right now. Water pipes at potential water deficit spots have been installed to solve the water problem. These pipes are supported by cemented objects placed at every 5 meters interval to avoid the damage and fall down of pipes due to water pressure, load and ground gravity. These pipes are used to transfer water from water surplus area to water deficit area. The 
Sustainability, Agri, Food and Environmental Research, (ISSN: 0719-3726), 9(3), 2021: 369-392 http://dx.doi.org/10.7770/safer-VONO-art2286

borings are done at high altitude i.e., Bhutan border as it becomes convenient to supply water from highland to lowland under the influence of gravity. The ground water level in the region is low that's why it is not feasible to use groundwater.

Water is renowned as one of the most vital resources available on the earth due to its multiple usages like drinking, bathing, cooking and various others. It is clearly said that if water sources are vanished then the life on the earth will become impossible. One of the participants replied that they preserved the sacred sources of origin of water in the region. If they don't preserve that water sources then, they will face a huge water scarcity during winter. They used to worship the place of origin of water sources and make people aware through their customs and rituals not to pollute the sacred. In their rituals and customs, they emphasized on the fact that it is one of the important parts of their life as well as provided free to us by the God. All of us should show our gratitude towards almighty by maintaining the purity of water.

Changing Agricultural Trend - Cash crops and one Time Investment: Male Totos are mainly involved in the cultivation of the betel nuts. The betel nuts plantations spread over vast area of Jalpaiguri district. The plant of betel nuts needs only one-time investment and after that it continue to gives betel year after year without any kind of investment throughout the life. The betel plants are resistant any kind of extreme weather conditions in the region whether dry winter or wet summer. The agro economy of the region is predominantly dependent on betel nuts and betel leaf. Betel nuts and its leaves are exported to different states like Madhya Pradesh, Uttar Pradesh and Bihar apart from consumed in west Bengal itself. The main exporters and buyers are business class like Bihari and Nepali. They buy at a meagre price from Toto and supply outside the at much higher purchase price and in this way, these communities exploit Totos. One of the participants replied that betel nuts and betel leaves are locally called as duab and purai or parai respectively. They also used to eat parai and betel on a daily basis. The unique quality of betel nuts is that it is not a perishable food item and can be stored without much care for several months.

\section{Role of Government}

The left (communist) government under the leadership of the Jyoti Basu and Buddhadeb Bhattacharjee did a lot of developmental work for promotion and upliftment of Toto tribe so that they could also become the of the main stream of the state. The then, government started several subsidy schemes for them like free ratio, health campus on a regular basis and conditional cash for the marriage of their sons and daughter. It also promotes them by providing monthly and yearly scholarships to Totos who clears class $8^{\text {th }}$ and class $10^{\text {th }}$ so that they can become the part of the mainstream society. One of the 
Sustainability, Agri, Food and Environmental Research, (ISSN: 0719-3726), 9(3), 2021: 369-392 http://dx.doi.org/10.7770/safer-V0N0-art2286

participants replied that those who clears $8^{\text {th }}$ and class $10^{\text {th }}$ with first division was given confirmed $C$ grade and $D$ grade job like primary school teacher. These are some of the reasons that's why the current Totos very much affectionate to the previous state governments.

Fig. 12 Children in Age-group 0-6 Years (Source Gram Panchayat, 2011)

Now, Trinamool Congress (right centred) government in the state has stopped several such schemes to Totos with the reason that there were some leakages in the execution part of it. This results a negative impact on the sustainable development of the tribe as the region is not connected via any mode of transport. One of the participants replied that Chitranjan Toto was the first among the entire tribe to pass class $10^{\text {th }}$ but he died just after 2-3 years as he was suffering by tuberculosis. Tuberculosis can be prevented by the proper treatment but in the region, there were no tertiary medical facilities to treat such kinds of disease. The 5-6 Totos together have opened a school as a token of tribute to the first $10^{\text {th }}$ passed Toto; Chitranjan Memorial School is the name of that school. There are no functional government schools in Toto's locality. Now, Totos have opened their own schools to improve the education level in their children (Fig. 12). Before this, they never go to the school. The current younger generations have had schools only, started going school and attaining formal education. They have requested to the current state government to start all earlier government welfare schemes at the soonest. Now, the Union government under the Pradhan Mantri Awaas Yojana has identified the needy Totos and constructing the home for them. Ministry of Rural Development is implementing the yojana in Totopara.

As suggestions and recommendations, the caring of Toto community is very important as they are the part of our intangible living heritage and will make incredible India more diverse and dignified. They are renowned as the soul and fuel of Alipurduar district of West Bengal. There are facing the existential threat as their survival nowadays is in danger. They want special reservation in the Scheduled Tribes (ST) reservation as they can't compete with other ST community in any of the government's job. They are highly illiterate and the consecutive government also didn't pay proper attention for enhancement of their education 
Sustainability, Agri, Food and Environmental Research, (ISSN: 0719-3726), 9(3), 2021: 369-392 http://dx.doi.org/10.7770/safer-V0N0-art2286

level. If we compete them with others, then they will never qualify any of the examinations as their base is very weak and are incompetent comparatively. Many of the Totos are suffering from several life-threatening diseases that could be easily cured if the region will have a better quality of primary and secondary health centres. If the disease is diagnosed at the initial stage, then it will be easily cured or the danger can be minimised, but for that we need the adequate number of primary and secondary health centres. A healthy body will work more efficiently than a sick one and for that the tribe needs a better amount of investment for sanitation. The sanitation facilities are not up to the mark because of the absence of suitable sewage and drainage facilities in their area.

Primary schools played a quite significant role in the growth and development of the children. Although, few schools are there, but the quality of the teacher is not good and they have not upgraded their knowledge and method of teaching. The empowered teachers are needed to serve the quality education to the ignited minds of the nation. Going to the school is a big challenge as the infrastructure logistics didn't match with other cities of the state. No roads are there to reach the school because there is a lack of coordination the Public Work Department (PWD) and the local authorities for road's construction. To reach the school students have to cross the river which is quite risky that's why many of the parents are uncomfortable to send their children to the school. Under the Pradhan Mantri Gram Sadak Yojana, the road should be constructed in their area so that the student can go to the school without any fear. They are living their life in a very pathetic condition still they are always in the hope that one day their life will definitely become better. They have understood that their life will only become better if they come forward and put their demands in front of their representatives and pressurise them in a decent manner. Hence, the fight is still going on.

There is a need to see the world from the eyes of Toto's perspective rather than from our perspective to them. We need to protect them as they are part of human heritage that embraces Toto's heritage in all its diversity. The number of Totos is decreasing day by day as they are neither the part of current economic system nor the local authorities are giving proper attention for their upliftment. The neglected attitude of the concerned authorities as they are mostly engaged in the lip service is also contributing in their downturn. In this regard, the entire community is facing an existential threat. Sometimes, constraints lead to creativity and creativity results in the development of the community despite all odds. The development that they have achieved is only because of the immense hard work and struggle behind it. The administration should implement "an eyes-on and hands-off policy" to protect them. The previous government's policies to protect Toto's were right and have to be implemented effectively. The focus should be on the concept of what can I give rather than what can I take. 
Sustainability, Agri, Food and Environmental Research, (ISSN: 0719-3726), 9(3), 2021: 369-392 http://dx.doi.org/10.7770/safer-V0N0-art2286

Unfortunately, authorities are involved in the idea of what can I take, then from there the process of corruptions starts. Their traditional knowledge of treatment of disease should be promoted and preserved. They are used to their own method of treatment rather than the modern medicinal approach. The government should be cautious to start any scheme in the area, keeping in mind their poor socio-economic status, belief, aloof ideology and adequate educational attainment.

The need of the hour is that all the concerned authorities like the state government, district administration and local authorities should come forward to improve Toto's living conditions. Otherwise, they will be completely wiped out over the years and we will lose one of the most important living heritages of the nation. Toto's have to be protected at least for the sake of human civilization.

\section{ACKNOWLEDGEMENT}

The authors are grateful to the Department of Geography, Delhi School of Economics, University of Delhi for proving adequate facilities to carry out the research.

\section{REFERENCES}

Basak, J. Majumdar, D. Pal, N. Paul, S. Mukhopadhyay, S. and Mukhopadhyay, A. (2009) Effort to Protect Totos, the Smallest Tribe in the World. American Society of Hematology, blood Journal, http://www.bloodjournal.org/content/114/22/5113?sso-checked=true.

Biswas, A. K. (2013). Impact of Modern Education in Toto Community. Contemporary Research in India, 3, 16-20.

Biswas, S.S. (2009) Socio-Economic Crisis and its Consequences on a Little-Known Tribal Community in West Bengal, India. Book Title: Identity in Crossroad Civilizations, Editors Erich Kolig, Vivienne SM. Angeles and Sam Wong Published by: Amsterdam University Press, pp.97-114, https://www.jstor.org/stable/j.ctt46n248.10, file://F:/Ph.\%20D\%201/Papers/Toto\%20Para/Sources/New\%20Sources/Biswas.pdf.

Census of India. (2011) Toto. http://www.censusindia.gov.in/2011documents/Isi/Isi_wb/5TOTO.pdf.

Chakrabarti, C.S. Roy, M. Sengupta, N. K. Lalthantluanga, R. and Majumder, P.P. (2002) Genetic Relationships among Some Tribal Groups Inhabiting the North-Eastern, Eastern and Sub-Himalayan Regions of India. Ann. Hum. Genet., Vol. 66, pp. 361-368, 
Sustainability, Agri, Food and Environmental Research, (ISSN: 0719-3726), 9(3), 2021: 369-392 http://dx.doi.org/10.7770/safer-V0N0-art2286

https://pdfs.semanticscholar.org/41d1/e4215742dd07f79e4e522d3c306538da728e.p df

Chakrabarty, P. and Sahu, S.S. (2013) The Toto Tribe in Transition: A Survey. ISSSN 07919016, Vol. 12, No. 2, Research Gate, https://www.researchgate.net/publication/329736183_The_Toto_Tribe_in_Transition A_Survey.

Chaudhary, S.R. (2009) North Bengal's Toto tribe close to total extinction. https://www.dnaindia.com/india/report-north-bengal-s-toto-tribe-close-to-totalextinction-1221613.

Dhargupta, A. Goswami, A. Sen, M. and Majumder, D. (2009) Study on the Effect of SocioEconomic Parameters on Health Status of the Toto, Santal, Sabar and Lodha Tribes of West Bengal, India. Studies of Tribes and Tribals, Vol.7 No. 1, pp. 31-38.

Das, J. (2011) Factors Influencing the Socio-Economic Status of Toto Tribe in Madarihat Block of Jalpaiguri District, West Bengal. Research Gate, Geo-Analyst, ISSN 2249-2909, Vol. 1, No. 2, pp. 66-71, https://www.researchgate.net/publication/265488725.

Das, A.K. (1999) Totos: A Primitive Tribe in Transition. Contemporary Society: Social Realities. Edited by Ratha, S.N. Feffer, G.P. and Behera, D.K. pp. 225-234.

Daw, S. (2015) Survival of the Endangered Sub Himalayan Adivasis: Totos in Contemporary India. Proceedings of the Indian History Congress, Vol. 76 (2015), pp. 908-917, https://www.jstor.org/stable/44156661, https://www.jstor.org/stable/pdf/44156661.pdf?refreqid=excelsior\%3Add832643de5 754efdabc0f6540af4fbd

Dawn, A. (2014) A Peep into The Lifestyle of the Endangered Toto Tribe of Jalpaiguri District of West Bengal. International Journal of Modern Research, Vol. 2, Issue 4, ISSN: 23478314, pp. 61-164, Available online at www.journalijmrr.com, http://journalijmrr.com/wp-content/uploads/2014/05/Anandita-Dawn161-164.pdf.

De, S. and Dutta, K. (2014) Multidimensional Poverty Index of Totos- The Smallest and Primitive Tribe in Jalpaiguri District of West Bengal. New Delhi Publisher, Economic Affairs, pp. 605-611.

Debnath, P. Das, P. and Saha A. (2019) Present Socio-Economic Scenario of Toto Tribe of Alipurduar. Research Review International Journal of Multidisciplinary, SSN 2455-3085 (Online), https://rrjournals.com/past-issue/present-socio-economic-scenario-of-tototribe-of-alipurduar/.

Devalle, S.B.C. (1990) Tribe in India: The Fallacy of a Colonial Category. Book Title: Studies on Asia and Africa from Latin America, Editor David N. Lorenzen, Published by Colegio 
Sustainability, Agri, Food and Environmental Research, (ISSN: 0719-3726), 9(3), 2021: 369-392 http://dx.doi.org/10.7770/safer-V0N0-art2286

de Mexico, https://www.jstor.org/stable/j.ctv3f8qc7.8, https://www.jstor.org/stable/pdf/j.ctv3f8qc7.8.pdf?ab_segments=0\%252Fdefault2\%252Fcontrol\&refreqid=excelsior\%3A2ef71ae6c97cbffae5c10bfbb871834e.

District Census Handbook. (2011) Jalpaiguri, Village and Town Directory, pp.112-190.

Dutta, R. (2014) Concept of Health, Disease and Treatment among the Totos of Totopara in Jalpaiguri District, West Bengal. Thesis, pp. 3-20.

Ghosal, A. (2016) Primitive Toto Tribe Seeks to have a Say: Amid Culture, Civilization and Cellphones, an Identity Crisis. The Indian Express Newspaper, https://indianexpress.com/article/elections-2016/india/india-news-india/primitivetoto-tribe-amid-culture-civilization-and-cellphones-an-identity-crisis-2757067/.

Ghosh, D. and Saha, S. (2017) Transformations of Traditional Livelihood and Economic Composition of Population: A Case Study of Totopara Village (West Bengal). OSR Journal of Humanities and Social Science (IOSR-JHSS), Vol. 22, No. 7, Ver. 7, e-ISSN: 2279-0837, p-ISSN: 2279-0845, pp. 1-8, www.iosrjournals.org, http://www.iosrjournals.org/iosr-jhss/papers/Vol.\%2022\%20Issue7/Version7/A2207070108.pdf.

Hoque, M.Z. and Ansar, M.K. (2015) Socio-Cultural and Economic Distinctiveness and Transformation of the Toto Tribe. International Journal of Innovative Research and Advanced Studies, Vol. 2, No. 5, ISSN 2394-4404, pp. 30-35, https://issuu.com/ijiras/docs/paper_8_c6faac230748a6.

Gupta, A.D. (2 013) Emerging Humanity in the Conservation of Biosphere Reserves, National Parks and Sanctuaries. 1-22, https://www.academia.edu/6866281/Toto_Primitive_Tribe_in_Conserving_Jaldapara _Wildlife_Sanctuary_IUAES.

Kalam. A.P.J.A. (2015) The Visionary. Jaipur Literary Festival.

Majumdar, B. (2013) A Sociological Study of the Toto Folk Tales. The Asiatic Society, ISBN10: 938157409X, ISBN-13: 978-9381574096.

Majumdar, B. (1998) The Totos: Cultural and Economic Transformation of a Small Tribe in the Sub-Himalayan Bengal. Academic Enterprise, University of Michigan, ISBN $8187121009,9788187121008$.

Mukherjee, B.N. Walter, K.C. Malhotra, K.C. Chakraborty, R. Sauber, P. Banerjee, S. and Manami Roy. (1987) Population genetic study in ten endogamous groups of West Bengal, India. Anthropologischer Anzeiger, Jahrg. Published by: E. Schweizerbart'sche Verlagsbuchhandlung, 45, H. 3, pp. 239-254, https://www.jstor.org/stable/29539805, 
Sustainability, Agri, Food and Environmental Research, (ISSN: 0719-3726), 9(3), 2021: 369-392 http://dx.doi.org/10.7770/safer-V0NO-art2286

file:///F:/Ph.\%20D\%201/Papers/Toto\%20Para/Sources/New\%20Sources/Mukherjee. pdf.

Mukherjee, U. (2017) The Tales of Vanishing Way of Life. The Telegraph, https://www.telegraphindia.com/opinion/tales-of-a-vanishing-way-oflife/cid/1460628.

North Bengal Development Department. (2019) About Toto People. Egiye Bangla, http://wbnorthbengaldev.gov.in/HtmlPage/toto.aspx.

Press Information Bureau. (2019) Development of Particularly Vulnerable Tribal Groups (PVTGs). Ministry of Tribal Affairs, Government of India, http://pib.nic.in/newsite/PrintRelease. aspx?relid=178257.

Saha, N. (1990) Distribution of Hemoglobin E in Several Mongoloid Populations of Northeast India. Human Biology, Published by Wayne State University Press, Vol. 62, No. 4, pp. 535-544, https://www.jstor.org/stable/41932347, https://www.jstor.org/stable/pdf/41932347.pdf?ab_segments=0\%252Fdefault2\%252Fcontrol\&refreqid=excelsior\%3A5c322cd32081d638a6d62718a821f7e3.

Sanyal, C.C. (1955) The Totos: A Sub Himalayan Tribe. Journal of Asiatic Society Science Vol. X.XI, No.2, pp.59-126.

Sanyal, C.C. (1973) The Meches and the Totos: Two Sub-Himalayan Tribes of North Bengal. Darjeeling, North Bengal University Press.

Sarkar, S. (2015) The Socio-Economic Status and Education of the Toto Community with Special Reference to Madarihat Block in the District of Alipurduar in West Bengal, India. Golden Research Thoughts, Vol. 4, pp. 1-8.

Sengupta, P. (2015) Capsulation of the Global Fitness Status and Body Composition of the Young Toto Women: The Smallest Tribal Community of India. Research Gate, Performance Enhance and Health, Journal Homepage: www.elsevier.com/locate/peh https://www.researchgate.net/publication/314116350.

Singh, G. (2017) A Rare Blood Disorder Could Wipe Out this Ancient Tribe. Narratively Super Subcultures, https://narratively.com/why-we-might-soon-lose-the-totos-oftotopara/.

Singh, S.S. (2019) Toto Language More Endangered than Tribe. The Hindu Newspaper, https://www.thehindu.com/news/cities/kolkata/toto-language-more-endangeredthan-tribe/article6270931.ece.

Sinha, D. and Pal, B.K. Population Dynamics among the Totos of West Bengal: A Positive Response to Culture Contact. Journal of Biosocial Science, pp. 237-245, 
Sustainability, Agri, Food and Environmental Research, (ISSN: 0719-3726), 9(3), 2021: 369-392

http://dx.doi.org/10.7770/safer-V0N0-art2286

https://pdfs.semanticscholar.org/36f2/e5caba60ac3e1f72d7a0d5e4013c124103f3.pd f.

Wenner-Gren Foundation. (1976) Impact of Industrialization on a Tribe in South Bihar, India. Current Anthropology, Published by The University of Chicago Press on behalf of Wenner-Gren Foundation for Anthropological Research, Vol. 17, No. 1, pp. 173-180, https://www.jstor.org/stable/2741620

Wolf, R.K. (2001) Three Perspectives on Music and the Idea of Tribe in India. Asian Music, Tribal Music of India, Published by University of Texas Press, Vol. 32, No. 1, pp. 5-34, https://www.jstor.org/stable/834329.

Xaxa, V. (1999) Transformation of Tribes in India: Terms of Discourage. Economic and Political Weekly, Published by: Economic and Political Weekly, Vol. 34, No. 24, pp. 1519-1524, https://www.jstor.org/stable/4408077, https://www.jstor.org/stable/pdf/4408077.pdf?ab_segments=0\%252Fdefault$2 \% 252$ Fcontrol\&refreqid $=$ excelsior\%3A52223f5d22ea04ed40ecaae23294c42f.

Received: 03 ${ }^{\text {th }}$ August 2020; Accepted: $14^{\text {th }}$ December 2020;

First distribution: $12^{\text {th }}$ January 2021.

Template for Interview - Appendix - 1

1. History and Background of Toto Tribes.

2. The population composition and trend of population growth of toto tribes.

3. Socio - Economic activity over the years.

4. Cultural and Linguistics issues

5. Major Issues and Concerns of the tribes over the years

6. What they feel and what can be done - Tribal Perception on their future.

7. Suggestion and Recommendations 